This would send a rather xenophobic message to potential international applicants and ultimately put the whole European project at risk. Brexit is thus a matter of concern on many different levels for the whole region.

The full report "Higher education and Brexit: current European perspectives" can be accessed at http://www.researchcghe.org/publications/higher-education-and-brexitcurrent-european-perspectives/

DOI: http://dx.doi.org/ı0.60I7/ihe.20I8.94.105I7

\section{India and China: Two Major Higher Education Hubs in Asia}

\section{P.J. LAVAKARE}

P.J. Lavakare is the former secretary of the Science Advisory Council, government of India, and the former executive director to the US-India Education Foundation, New Delhi, India. E-mail: lavakarepj@gmail. com.

Tndia and China are considered to be potential major 1 hubs in Asia for international students. Both have large and diverse higher education systems. Students from both countries are keen to enter the global employment market. It is this challenge that demands the respective national education systems produce "global citizens" with the highlevel, high-quality, diverse, and international educational backgrounds needed on the global market. International higher education also involves having a diverse international student population enrolled in local higher education institutions (HEI). Both countries are trying to attract large numbers of international students into their systems. This article briefly reviews the international education status of India and China and highlights some crucial parameters governing the two systems.

\section{Higher Education Infrastructure}

India has 799 universities and nearly 38,000 (mainly undergraduate) affiliated colleges; China has 2,880 universities. Their respective national enrollments are 34.5 million and 47.9 million. Both systems encourage the establishment of private HEIs. China has made major efforts to improve more than Ioo of its universities, and seven of them are now ranked in the top 200 by the Times Higher Education (THE) world university ranking. India has been tinkering with some reforms, trying to improve its top universi- ties, but so far none of the Indian universities are ranked in the top 200 globally. In spite of the fact that English is the language of instruction at most Indian HEIs, they have not been able to attract international students because of their poor ranking. Chinese universities have gone out of their way in this regard and are offering programs taught in English at some of their good universities. Chinese English-medium medical institutions are even attracting students from India, as Chinese authorities have ensured that these institutions are recognized by the Medical Council of India. India has not made any such major reform to attract international students. Further, China has set up the China Scholarship Council (CSC) as a nonprofit organization under the Chinese ministry of education, offering scholarships to international students to study in China. This council also offers scholarships to Chinese students for study abroad. The Indian agency coordinating the higher education sector, the University Grants Commission (UGC), does not have any such promotional measures to attract international students or to encourage Indian students to get international exposure. Clearly, the Chinese educational infrastructure is significantly more favorable to international education and international students.

\section{Student Mobility in India And China}

The mobility of both inbound and outbound students has become an important dimension of internationalization programs. In 20I5, there were 181,872 Indian students studying abroad, while during the same period, 523,700 Chinese students were studying abroad. India does not restrict studying abroad, but, unlike China, it does not offer many scholarships. While India has demonstrated steady growth, China has shown sizable upward and downward variations. But the trend is clear: China is keen to expose its students to study abroad and has taken concrete steps to provide them with national scholarships. In India, a few elite institutions like the Indian Institutes of Technology (IITs) have recently started some internship abroad programs for their engineering students, with some scholarship support and the help of partner institutions. In the long run, the well-educated Chinese workforce will definitely provide tough competition to young Indian professionals seeking employment abroad. The Chinese are catching up on their English language skills, which for many years have been a great advantage for Indian students.

The most noticeable change in the internationalization programs of India and China is in the area of receiving international students. In 20I5, India attracted only 42,420 international students, while, that same year, China was able to attract 397,635 international students. This was a result of a major national initiative, the establishment of the CSC, which not only helps to centrally recruit international 
students but also offers them scholarships based on merit. India has yet to set up such a centrally coordinated agency. The impact of this initiative is that Io percent of globally mobile students are now studying in China. China has even been successful in attracting Indian students, with the Indian student population in China growing from 8,I45 in 2008 to 16,694 in 2015 . Interestingly, 80 percent of these students are pursuing undergraduate, English-medium medical degrees. In comparison, data provided by the All India Survey for Higher Education (AISHE) of the Indian ministry of human resource development reveals a total of only I85 Chinese students studying in India during 20I520I6. The majority of these students study commerce, management, computer science, and other sciences. This imbalance clearly shows that, within Asia, China is a more attractive education hub.

\section{The mobility of both inbound and out- bound students has become an impor- tant dimension of internationalization programs.}

To attract international students (and provide international quality education to its own students), China has encouraged four accredited American HEIs to set up a base in China. India's policy toward foreign education providers wishing to establish campuses in India has been very restrictive. As a result, not a single foreign institution has been attracted to set up a campus on Indian soil.

\section{CONCLUSION}

Both India and China have very large and comparable higher education infrastructures. In a globalized world, both have the potential to attract a large number of international students from other parts of the world-both developed and developing. China has recognized the importance of undertaking reforms to internationalize its higher education. As mentioned above, seven of its universities are now ranked among the top 200 worldwide, it attracts Io times more international students than India, and it is also ensuring that a significant portion of its own student population is exposed to education abroad. India has made no such efforts. As a result, Chinese students studying abroad outnumber Indian students and enter the global employment market with an advantage. China has opened its doors to quality foreign university campuses attracting foreign as well as local students. Unless India takes very aggressive measures to reform its higher education system, it will lose the race to China as Asia's most attractive education hub. Higher education is a means for economic development. The ministry of human resource development and the ministry of commerce in India must join efforts to develop a new plan to ensure economic development through higher education.

DOI: http://dx.doi.org/ıo.6oI7/ihe.2018.94.10518

\section{“Super-Short-Term" Study Abroad in Japan: A Dramatic Increase}

\section{Yukıко SHIMmI}

Yukiko Shimmi is assistant professor at the Graduate School of Law and the Center for Global Education, Hitotsubashi University, Tokyo, Japan.E-mail:yshimmi@gmail.com.

ince the mid-200os, Japanese students have reportedly $\checkmark$ been developing an "inward-looking" attitude (some likely reasons are discussed in an article by Shimmi in IHE, issue 66,2012$)$. In recent times, there has been a dramatic increase of students participating in "super-short-term" study-abroad programs, lasting from one week up to one month. According to the Japan Student Service Organization (JASSO), the number of Japanese students who participated in such super-short-term programs more than tripled between 2009 and 2016 , increasing from 16,873 to $60, \mathrm{I} 45$. This reflects a growing global trend among college students, especially in developed countries. This article discusses the background of this trend in Japan as well as emerging challenges.

\section{The Japanese Government's New Policies on Studying ABROAD}

During the postwar period, the central focus of the Japanese government's internationalization policy was on attracting international students to come and study in Japan. However, with the decline, from the late 2000 , of the number of Japanese students studying abroad, the government (under the Abe administration) started prioritizing the promotion of outbound mobility in order to foster a globally-minded workforce for Japanese companies. Until that point, studying abroad had been mainly considered as a private choice, and governmental support for Japanese students to study abroad had been limited. In its effort to promote study abroad, the government increased scholarships available 